\title{
Effect of ruminal administration of Escherichia coli wild type or a genetically modified strain with enhanced high nitrite reductase activity on methane emission and nitrate toxicity in nitrate-infused sheep
}

\author{
C. Sar ${ }^{1}$, B. Mwenya ${ }^{1}$, B. Pen ${ }^{1}$, K. Takaura ${ }^{1}$, R. Morikawa ${ }^{1}$, A. Tsujimoto ${ }^{1}$, K. Kuwaki $^{1}$, N. Isogai ${ }^{2}$, I. Shinzato ${ }^{2}$, \\ Y. Asakura ${ }^{2}$, Y. Toride ${ }^{2}$ and J. Takahashi ${ }^{1 *}$ \\ ${ }^{1}$ Department of Animal Science, Obihiro University of Agriculture and Veterinary Medicine, Obihiro, Hokkaido 080-8555, Japan \\ ${ }^{2}$ Fermentation and Biotechnology Laboratories, Global Foods and Amino Acids Company, Ajinomoto Co. Inc., 1-1, Suzuki-cho, \\ Kawasaki-ku, Kawasaki-shi, 210-8681, Japan
}

(Received 16 February 2005 - Revised 4 May 2005 - Accepted 9 May 2005)

\begin{abstract}
The effects of two kinds of Escherichia coli (E. coli) strain, wild-type E. coli W3110 and E. coli nir-Ptac, which has enhanced $\mathrm{NO}_{2}$ reduction activity, on oral $\mathrm{CH}_{4}$ emission and $\mathrm{NO}_{3}$ toxicity in $\mathrm{NO}_{3}$-treated sheep were assessed in a respiratory hood system in a $4 \times 6$ Youden square design. $\mathrm{NO}_{3}(1 \cdot 3 \mathrm{~g} \mathrm{NaNO} /$ $\mathrm{kg}^{0.75}$ body weight) and/or E. coli strains were delivered into the rumen through a fistula as a single dose 30 min after the morning meal. Escherichia coli cells were inoculated for sheep to provide an initial $E$. coli cell density of optical density at $660 \mathrm{~nm}$ of 2, which corresponded to $2 \times 10^{10}$ cells $/ \mathrm{ml}$. The six treatments consisted of saline, E. coli W3110, E. coli nir-Ptac, $\mathrm{NO}_{3}, \mathrm{NO}_{3}$ plus E. coli W3110, and $\mathrm{NO}_{3}$ plus E. coli nir-Ptac. $\mathrm{CH}_{4}$ emission from sheep was reduced by the inoculation of $E$. coli $\mathrm{W} 3110$ or $E$. coli nir-Ptac by $6 \%$ and $12 \%$, respectively. $\mathrm{NO}_{3}$ markedly inhibited $\mathrm{CH}_{4}$ emission from sheep. Compared with sheep given $\mathrm{NO}_{3}$ alone, the inoculation of $E$. coli W3110 to $\mathrm{NO}_{3}$-infused sheep lessened ruminal and plasma toxic $\mathrm{NO}_{2}$ accumulation and blood methaemoglobin production, while keeping ruminal methanogenesis low. Ruminal and plasma toxic $\mathrm{NO}_{2}$ accumulation and blood methaemoglobin production in sheep were unaffected by the inoculation of $E$. coli nir-Ptac. These results suggest that ruminal methanogenesis may be reduced by the inoculation of $E$. coli W3110 or E. coli nir-Ptac. The inoculation of $E$. coli W3110 may abate $\mathrm{NO}_{3}$ toxicity when $\mathrm{NO}_{3}$ is used to inhibit $\mathrm{CH}_{4}$ emission from ruminants.
\end{abstract}

Escherichia coli W3110: Escherichia coli nir-Ptac: Methane emission: Nitrate

The interaction between ruminant animals and ruminal microorganisms is clearly symbiotic (Van Kessel \& Rusell, 1996). The animal provides the micro-organism with a habitat for growth, and the micro-organisms, in turn, provide the animal with fermentation acids and microbial protein (Hungate, 1966). $\mathrm{CH}_{4}$ is also a major end product of ruminal fermentation and represents the loss of $2-12 \%$ of the gross energy consumed by ruminants (Johnson \& Johnson, 1995). Additionally, $\mathrm{CH}_{4}$ is a greenhouse gas implicated as a contributor to global warming (Moss, 1993). An inhibition of $\mathrm{CH}_{4}$ production by ruminants would therefore have significant economical and environmental benefits (Van Nevel \& Demeyer, 1996).

Attempts to identify specific chemical inhibitors of $\mathrm{CH}_{4}$ production have largely been unsuccessful (Van Nevel \& Demeyer, 1996). An alternative strategy to reduce ruminal methanogenesis is to promote alternative metabolic pathways to dispose of the reducing power, competing with methanogenesis for $\mathrm{H}$ uptake (López et al. 1999). The administration of $\mathrm{NO}_{3}$ remarkably inhibited ruminal methanogenesis in vitro (Jones, 1972; Sar et al. 2005a) and in vivo (Takahashi \& Young, 1991, 1992). However, elevated levels of $\mathrm{NO}_{3}$ in feeds and water could pose a serious threat to animals owing to its conversion to toxic $\mathrm{NO}_{2}$ in the rumen, subsequently causing methaemoglobin formation in the blood (Takahashi \& Young, 1991, 1998; Sar et al. 2004a). The accumulation of ruminal toxic $\mathrm{NO}_{2}$ is often the result of a usually faster reduction of $\mathrm{NO}_{3}$ to $\mathrm{NO}_{2}$ than of $\mathrm{NO}_{2}$ to $\mathrm{NH}_{3}$ (Takahashi et al. 1998). Stimulating ruminal $\mathrm{NO}_{2}$ reduction to $\mathrm{NH}_{3}$ is therefore an effective way of preventing $\mathrm{NO}_{2}$ toxicity.

Wild-type Escherichia coli (E. coli) W3110 is known to have a certain $\mathrm{NO}_{2}$ reductase activity in which $\mathrm{NO}_{2}$ reductase has two subunits encoded by the nirBD operon. This enzyme, involved in $\mathrm{NO}_{3}$ respiration, is induced in $\mathrm{O}_{2}$-limited conditions (Gennis \& Stewart, 1996). Escherichia coli nir-Ptac, constructed by replacing the promoter of the nirBD in E. coli $\mathrm{W} 3110$ by the tac promoter (Ajinomoto Co. Inc., Tokyo, Japan), showed twice as high an $\mathrm{NO}_{2}$ reductase activity as was seen in E. coli W3110. Later, Sar et al. (2005b) indicated that E. coli W3110 and E. coli nirPtac inhibited toxic $\mathrm{NO}_{2}$ accumulation and decreased $\mathrm{CH}_{4}$ production in mixed ruminal cultures supplemented with $\mathrm{NO}_{2}$, but did not inhibit it in mixed ruminal cultures supplemented with $\mathrm{NO}_{3}$, although a decrease in $\mathrm{CH}_{4}$ production was observed.

The objective of this study was therefore to evaluate the effects of two kinds of $E$. coli strain, wild-type E. coli $\mathrm{W} 3110$ and $E$. coli nir-Ptac (which has enhanced $\mathrm{NO}_{2}$ reduction activity), on ruminal fermentation characteristics, $\mathrm{CH}_{4}$ emission and $\mathrm{NO}_{3}$ toxicity in $\mathrm{NO}_{3}$-infused sheep. 


\section{Materials and methods}

\section{Experimental design, animal feeding and additives}

Four ruminally fistulated Cheviot wethers $(53.25$ (SD 4.01) kg) were individually kept in metabolic crates equipped with a ventilated respiratory collection hood and allocated in a $4 \times 6$ Youden square design. The animals were fed with twice daily $(08.00$ and $17.00 \mathrm{~h})$ with a maintenance level of energy $\left(55 \mathrm{~g} \mathrm{DM} / \mathrm{kg}^{075}\right.$ body weight per d) with a basal diet comprising Italian ryegrass, alfalfa hay cubes and a concentrate (in g/kg: dry matter (DM) 881.6; organic matter (OM) 940.3; dietary crude protein (CP) 192.6; acid detergent fibre (ADF) 75.0; neutral detergent fibre (NDF) 224.0; acid detergent lignin (ADL) 22.7; gross energy (GE) $19.00 \mathrm{MJ} / \mathrm{kg} \mathrm{DM}$ ) in the ratio 40:40:20 on a DM basis. Each sheep had free access to water and a block of trace mineralised salt (Fe 1232, Cu 150, Co 25, Zn 500, I 50, Se 15, Na $382 \mathrm{mg} / \mathrm{kg}$ ). Each period lasted $8 \mathrm{~d}$, comprising $7 \mathrm{~d}$ for acclimatisation to feeds and $1 \mathrm{~d}$ for the measurement of respiratory gas exchange and metabolic rate, as well as the simultaneous collection of ruminal fluid and blood. One week was allowed between treatments to assure that there were no carry-over effects of previous treatment.

The six treatments consisted of saline, inoculated wild-type E. coli W3110, inoculated E. coli nir-Ptac, $\mathrm{NO}_{3}, \mathrm{NO}_{3}$ plus E. coli $\mathrm{W} 3110$ and $\mathrm{NO}_{3}$ plus E. coli nir-Ptac. Physiological saline $\left(0.9 \% \mathrm{NaCl}\right.$; same volume as that of infused $\left.\mathrm{NO}_{3}\right)$ administered as the control treatment was infused into the rumen through the ruminal fistula $30 \mathrm{~min}$ after the morning feeding. A $300 \mathrm{~g} / \mathrm{l}$ aqueous solution of $1.3 \mathrm{~g} \mathrm{NaNO}_{3} / \mathrm{kg}^{075}$ body weight, considered to be able to induce a subclinical $\mathrm{NO}_{3}$ toxicity (Takahashi \& Young, 1991), was administered via the ruminal fistula $30 \mathrm{~min}$ after the morning feed. To test the suppressant effects of wildtype E. coli W3110 and E. coli nir-Ptac on the $\mathrm{NO}_{3}$-induced poisoning, respiratory gaseous exchange, metabolic rate and characteristics of ruminal fermentation, both $E$. coli strains (wild-type E. coli and E. coli nir-Ptac) and/or $\mathrm{NO}_{3}$ were administered into the rumen through the ruminal fistula as a single dose $30 \mathrm{~min}$ after the morning feeding once on the sampling day. The cells of E. coli W3110 or E. coli nir-Ptac were inoculated for sheep to provide an initial $E$. coli cell density of an optical density at $660 \mathrm{~nm}$ (OD660) of 2 (Sar et al. 2005a), which corresponded to approximately $2 \times 10^{10}$ cells $/ \mathrm{ml}$.

The sheep were weighed weekly prior to the beginning of each period to determine the daily allowance of feed and dosages of $\mathrm{NO}_{3}$. The oral exchange of respiratory gases was monitored from $1 \mathrm{~h}$ before to $9 \mathrm{~h}$ after feeding the morning meal. Ruminal fluid was collected at $1,2,3,4,5,6,7,8$ and $9 \mathrm{~h}$ through a rumen fistula equipped with a valve to avoid any losses of gases during sampling using a hand syringe. Blood was collected via a jugular catheter $1,3,5,7$ and $9 \mathrm{~h}$ after an administration of the chemicals and inoculation of E. coli strains. The experimental protocol was approved by Obihiro University of Agriculture and Veterinary Medicine Committee for Animal Use and Care.

\section{Genetic modification}

Escherichia coli nir-Ptac was constructed by replacing the promoter region upstream of the chromosomal nirBD genes of wild-type E. coli $\mathrm{W} 3110$ by the tac promoter. First, a $3 \mathrm{kbp}$ DNA fragment of the nirBD gene was amplified by PCR using E. coli W3110 chromosomal DNA as the template and oligonucleotides 5'-AAA AGA ATTCGAGGCAAA AATGAGCAA AGT-3' and
5'-CCCCAA GCT TCATGCAAA AAGGGGAGGCAT- $3^{\prime}$ as the primers, and was cloned into the Eco RI-HindIII site of an E.coli expression vector pKK223-3 (Amersham Pharmacia Biotech, New York, USA), containing the tac promoter so that the nirBD gene was expressed under the regulation of the $t a c$ promoter. Then, using this plasmid as the template, PCR was performed using oligonucleotides $5^{\prime}$-CGGGGTACCTTC TGGCGTCAGGCAGCCAT- $3^{\prime}$ and 5'-ACATGCATGCCGTCTACGCCCAGCAGTTTC- $3^{\prime}$ as the primers, which gave a $2 \mathrm{kbp}$ DNA fragment with $200 \mathrm{bp}$ of the pKK223-3 vector-derived sequence containing the tac promoter, followed by a $1.8 \mathrm{kbp}$ sequence of the nirBD. The primers were designed so that the amplified DNA fragment had a Kpn I site at its $5^{\prime}$ end (at the end of the vector-derived region) and a $S p h \mathrm{I}$ site at its $3^{\prime}$ end (at the end of the nirBD gene-derived region). The amplified DNA fragment was digested with $K p n \mathrm{I}$ and $S p h \mathrm{I}$ and was designated fragment 1.

Another PCR was performed using E. coli W3110 chromosome DNA as the template, and oligonucleotides $5^{\prime}$-CGGAATTCGTATGAAGGGCGTCAGCGCG-3' and 5'-CGGGGTACCTTCTTA AGTCACGGA ATTGT- $3^{\prime}$ as the primers, which gave a $1 \mathrm{kbp}$ DNA fragment with its $3^{\prime}$ end $121 \mathrm{bp}$ upstream of the start codon of the nirB gene. The primers were designed so that the amplified DNA fragment had an Eco RI site at its $5^{\prime}$ end (at the end furthest from the nirB gene) and a Kpn I site at its $3^{\prime}$ end (the end closer to the nirB gene). The amplified DNA fragment was digested with Eco RI and Kpn I, and was designated fragment 2.

Fragments 1 and 2 were ligated into the Eco RI and Sph I site of E. coli vector plasmid pHSG299 in the order of Eco RI-fragment 2 -fragment $1-S p h$ I. The constructed plasmid was designated pHSG-nir-Ptac. From pHSG-nir-Ptac, the inserted DNA fragment was cut out with Hind III and ligated into Hind III sites of temperature-sensitive vector plasmid, pMAN997, which is a derivative of vector plasmid pMAN031 (Matsuyama \& Mizushima, 1985). The resulting plasmid was designated pMAN-nirPtac. Wild-type E. coli W3110 was transformed with pMANnir-Ptac and cultured at a non-permissive temperature, and the clones with the promoter upstream of nirBD replaced by tac promoter were selected. The clone was designated nir-Ptac.

To measure the $\mathrm{NO}_{2}$ reductase activity of the nir-Ptac, the E. coli nir-Ptac cells were cultured in a $500 \mathrm{ml}$ flask containing $20 \mathrm{ml}$ media (40 g glucose/l, $1 \mathrm{~g} \mathrm{MgSO}_{4} \cdot 7 \mathrm{H}_{2} \mathrm{O} / \mathrm{l}, 24 \mathrm{~g}\left(\mathrm{NH}_{4}\right)_{2} \mathrm{SO}_{4} / \mathrm{l}, 1 \mathrm{~g} \mathrm{KH}_{2} \mathrm{PO}_{4} /$ $1,10 \mathrm{mg} \mathrm{MnSO}_{4} \cdot 7 \mathrm{H}_{2} \mathrm{O} / 1,10 \mathrm{mg} \mathrm{FeSO} \cdot \cdot 7 \mathrm{H}_{2} \mathrm{O} / 1,2 \mathrm{~g}$ yeast extract/l, $30 \mathrm{~g} \mathrm{CaCO}_{3} / 1,10 \mathrm{mM}-\mathrm{KNO}_{2} ; \mathrm{pH} \mathrm{7.0)}$ with constant shaking at $37^{\circ} \mathrm{C}$ for $11 \mathrm{~h}$. The OD660 and $\mathrm{NO}_{2}$ concentration in the culture media were measured every $1-2 \mathrm{~h}$, and the $\mathrm{NO}_{2}$ reductase activity (reduced $\mathrm{NO}_{2}, \mathrm{~mm} / \mathrm{h}$ per $\mathrm{g}$ dry cells) was calculated by dividing the volumetric rates of $\mathrm{NO}_{2}$ reduction by the respective values for cell mass. The dry cell weight was calculated from the OD660 by an experimentally obtained formula:

$$
\text { Dry cell weight }=0 \text { D660 } \times 0.67+0.002
$$

Escherichia coli $\mathrm{W} 3110$ or E. coli nir-Ptac cells were anaerobically grown on the Luria-Bertani broth agar (Sanko Junyaku Co. Ltd. Tokyo, Japan) at $37^{\circ} \mathrm{C}$ for $10 \mathrm{~h}$ and inoculated into each $5000 \mathrm{ml}$ flask containing $1000 \mathrm{ml}$ Luria-Bertani broth (10 g tryptone, $5 \mathrm{~g}$ yeast extract, $10 \mathrm{~g} \mathrm{NaCl} / \mathrm{l})$ and cultured for $16 \mathrm{~h}$ at $37^{\circ} \mathrm{C}$ with constant shaking (120 rpm). Stationary-phase cells were harvested by centrifugation $\left(15000 \mathrm{~g}, 8 \mathrm{~min}, 4^{\circ} \mathrm{C}\right)$, washed in sterile buffer solution ( $\mathrm{pH} 6 \cdot 8$; McDougall, 1948) and resuspended in the sterile buffer solution. 


\section{Experimental measurements}

$\mathrm{CO}_{2}$ and $\mathrm{CH}_{4}$ production and $\mathrm{V}_{\mathrm{O}_{2}}$ were monitored by a fully automated open-circuit respiratory system using a hood over the sheep's head, as reported by Takahashi et al. (1998). Metabolic rate (W) was calculated using the equation of Brouwer (1960). The rate of methanogenesis in the rumen was estimated from respiratory $\mathrm{CH}_{4} \cdot \mathrm{CO}_{2}, \mathrm{O}_{2}$ and $\mathrm{CH}_{4}$ concentrations were measured as reported by Takahashi et al. (1998). Data were collected and entered into a computer from the analysers through an interface at $1 \mathrm{~min}$ intervals and then automatically standardised at $0^{\circ} \mathrm{C}$, $1013 \mathrm{hPa}$ and zero water vapour pressure.

The values of $\mathrm{pH}$ and redox potential (ORP) in ruminal fluid were measured using a $\mathrm{pH}$ and ORP meter (HM-21P; TOA Electronics Ltd. Tokyo, Japan), and then each sample was not acidified and was frozen at $-20^{\circ} \mathrm{C}$ for later determination of ruminal $\mathrm{NO}_{3}, \mathrm{NO}_{2}, \mathrm{NH}_{3}-\mathrm{N}$, and volatile fatty acids (VFA). $\mathrm{NO}_{3}$ and $\mathrm{NO}_{2}$ concentration in the rumen were measured using the $\mathrm{NO}_{3} / \mathrm{NO}_{2}$ Assay Kit-C (Colorimetric; Dojindo, Kumamoto, Japan). The absorption coefficient was measured using a microplate reader (ELSIA Reader; Otsuka Electronics Co. Ltd, Osaka, Japan). $\mathrm{NH}_{3}-\mathrm{N}$ concentration in the rumen was estimated as previously described (Sar et al. 2004b). The concentrations of VFA in the rumen were analysed by GLC (Shimadzu GC14A; Shimadzu, Kyoto, Japan) equipped with a flame-ionisation detector and a capillary column (ULBON HR-52, 0.53 mm inner diameter $\times 30 \mathrm{~m}$; Shinwa, Kyoto, Japan) by using 2-ethyl- $n$-butyric acid as the internal standard. Values were calculated automatically using a Chromatopac data processing system (C-R 4A; Shimadzu).

Ruminal juice for ciliate protozoal enumeration was collected $5 \mathrm{~h}$ after feeding and supplementation. Ruminal fluid $(1 \mathrm{ml})$ was diluted with $9 \mathrm{ml}$ methylgreen-formaline-saline solution, and ciliate protozoa were enumerated using a Fuchs-Rosenthal counting chamber (Hausser Scientific Partnership, Horsham, PA, USA) as previously described (Ogimoto \& Imai, 1981).

Venous blood collected from a jugular catheter was used to determine concentrations of $\mathrm{Hb}$ (Nescauto Hemokit-N; Azwell Inc., Osaka, Japan) and methaemoglobin (Evelyn and Malloy, 1938). Plasma $\mathrm{NO}_{2}$ concentration was measured as described for ruminal fluid.

\section{Statistical analysis}

Statistical analysis for Youden square experiments using the MIXED procedure of SAS (SAS Institute Inc., Cary, NC, USA) examined the effects of sheep, period and supplementary treatment in the model. Excluding data on protozoa, all data were analysed using the MIXED SAS procedure for repeated measures (Littell et al. 1998). Data on protozoa were analysed by ANOVA using the MIXED SAS procedure. Differences between treatments were determined using the least squares means procedure (PDIFF option) of SAS. Statistical significance of differences was taken as $P<0.05$, and trends were considered when $0.05<P<0.10$ unless otherwise indicated.

\section{Results}

\section{Methane emission}

Table 1 shows that mean $\mathrm{CH}_{4}$ production in sheep was decreased $(P<0.001)$ by the addition of $\mathrm{NO}_{3}$ compared with saline-infused sheep. Compared with saline-infused sheep, the mean $\mathrm{CH}_{4}$ production in sheep was decreased by the inoculation of $E$. coli W3110 $(P=1 \cdot 109)$ or $E$. coli nir-Ptac $(P=0.004)$. The inoculation of E. coli W3110 or E. coli nir-Ptac did not change the effect of $\mathrm{NO}_{3}$ on mean $\mathrm{CH}_{4}$ production in sheep. Fig. 1 shows that the rate of $\mathrm{CH}_{4}$ production in sheep given $\mathrm{NO}_{3}$ declined rapidly $(P<0.001)$ compared with that in saline-infused sheep $1 \mathrm{~h}$ after the administration of $\mathrm{NO}_{3}$. Although significant differences were not observed, the rate of $\mathrm{CH}_{4}$ production in sheep inoculated with E. coli W3110 compared with saline-infused sheep decreased numerically $(P>0.05)$ after $1 \mathrm{~h}, 3-5 \mathrm{~h}$ and $7 \mathrm{~h}$ after inoculation of E. coli W3110. Compared with saline-infused sheep, the rate of $\mathrm{CH}_{4}$ production in E. coli nir-Ptac inoculated sheep decreased after $1-2 \mathrm{~h}(P>0.05)$ and $4-7 \mathrm{~h}(P=0 \cdot 10)$ of the inoculation of $E$. coli nir-Ptac. When E. coli $\mathrm{W} 3110$ or $E$. coli nir-Ptac was inoculated into $\mathrm{NO}_{3}$-infused sheep, the rate of $\mathrm{CH}_{4}$ production was unaffected $(P>0.05)$ compared with sheep infused with $\mathrm{NO}_{3}$ alone.

\section{Nitrate disappearance and nitrite accumulation in the rumen, plasma nitrite formation and blood methaemoglobin}

Fig. 2 (A) shows the disappearance of $\mathrm{NO}_{3}$ in the rumen. Compared with sheep given $\mathrm{NO}_{3}$ alone, the $\mathrm{NO}_{3}$ concentration was decreased $(P=0.095)$ by the inoculation of $E$. coli nir-Ptac to $\mathrm{NO}_{3}$-infused sheep, a further decrease $(P=0 \cdot 008)$ being observed with the inoculation of $E$. coli $\mathrm{W} 3110$ to $\mathrm{NO}_{3}$-infused sheep. Fig. 2 (B) shows the accumulation of $\mathrm{NO}_{2}$ in the rumen.

Table 1. Blood methaemoglobin, $\mathrm{O}_{2}$ consumption, $\mathrm{CO}_{2}$ and $\mathrm{CH}_{4}$ production, and metabolic rate in sheep given $\mathrm{NO}_{3}$ and/or Escherichia coli W3110 or E. coli nir-Ptac

Treatment

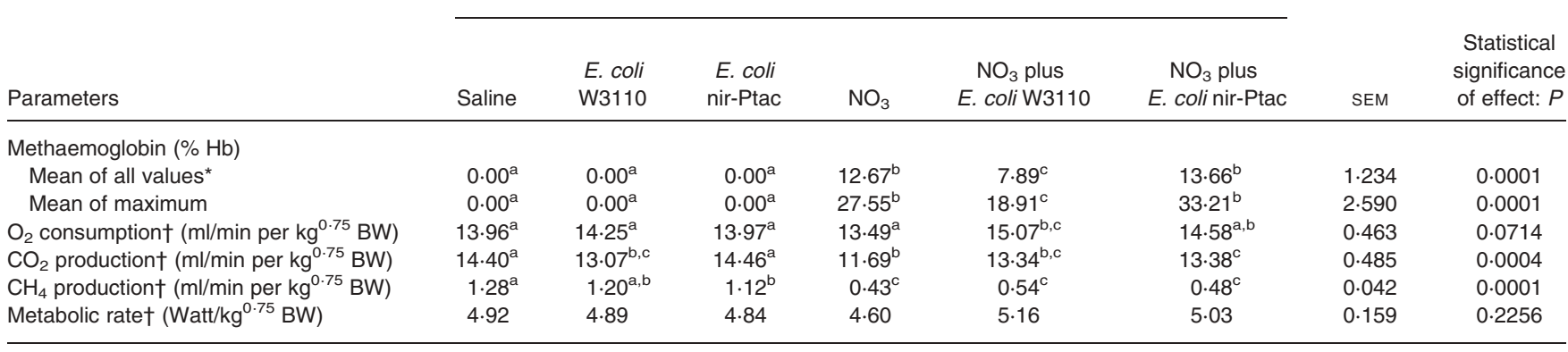

BW, body weight.

${ }^{*}$ Value is mean of five sampling times.

${ }^{\text {abc }}$ Mean values within a row with unlike superscript letters were significantly different $(P<0.05)$ each value indicates mean of four animals

tValue is the mean of $9 \mathrm{~h}$ observation. 


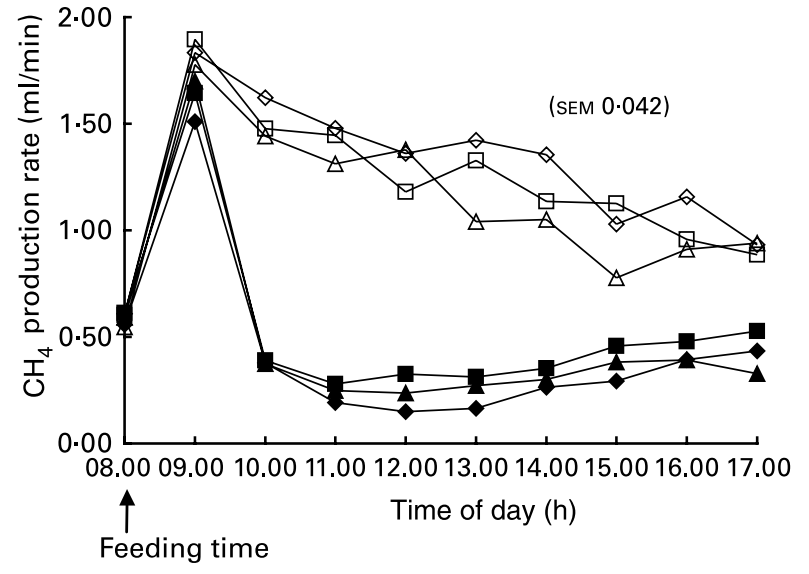

Fig. 1. Diurnal changes in $\mathrm{CH}_{4}$ emission from sheep given saline $(\diamond)$, E. coli $\mathrm{W} 3110(\square)$, E. coli nir-Ptac $(\triangle), \mathrm{NO}_{3}(\diamond), \mathrm{NO}_{3}$ plus E. coli $\mathrm{W} 3110(\square)$ and $\mathrm{NO}_{3}$ plus $E$. coli nir-Ptac $(\mathbf{\Lambda})$.

The accumulation of $\mathrm{NO}_{2}$ peaked $4 \mathrm{~h}$ after $\mathrm{NO}_{3}$ had been administered to the sheep. When E. coli W3110 was inoculated into $\mathrm{NO}_{3}$-infused sheep, both peak $(P=0.049)$ and mean $(P<0.001)$ $\mathrm{NO}_{2}$ accumulation decreased compared with the values in sheep given $\mathrm{NO}_{3}$ alone. Compared with sheep given $\mathrm{NO}_{3}$ alone, $\mathrm{NO}_{2}$ accumulation in sheep given $\mathrm{NO}_{3}$ plus E. coli nir-Ptac decreased initially and then declined rapidly after the $3 \mathrm{~h}$ peak had been obtained, and the mean $\mathrm{NO}_{2}$ accumulation also decreased $(P=0.075)$.

Figure $2(\mathrm{C})$ shows $\mathrm{NO}_{2}$ formation in the plasma. Plasma $\mathrm{NO}_{2}$ concentration peaked $5 \mathrm{~h}$ after $\mathrm{NO}_{3}$ had been administered to the sheep. Compared with sheep given $\mathrm{NO}_{3}$ alone, a decrease in both peak $(P<0.001)$ and mean $(P=0.014)$ plasma $\mathrm{NO}_{2}$ concentration was observed in sheep given $\mathrm{NO}_{3}$ and $E$. coli W3110. When $E$. coli nir-Ptac was inoculated to $\mathrm{NO}_{3}$-infused sheep, both peak and mean plasma $\mathrm{NO}_{2}$ concentrations were unaffected compared with the sheep given $\mathrm{NO}_{3}$ alone.

Figure 2 (D) shows the formation of blood methaemoglobin in sheep. Blood methaemoglobin concentration in any of the saline-infused groups of sheep was below the detection level. The methaemoglobin level of total blood $\mathrm{Hb}$ peaked $7 \mathrm{~h}$ after the sheep had been infused with $\mathrm{NO}_{3}$. When E. coli W3110 was inoculated into the $\mathrm{NO}_{3}$-infused sheep, peak values of blood methaemoglobin decreased $(P<0.001)$ compared with sheep given $\mathrm{NO}_{3}$ alone. The inoculation of E. coli nir-Ptac to the $\mathrm{NO}_{3}$-infused sheep did not affect the peak values of blood methaemoglobin compared with sheep given $\mathrm{NO}_{3}$ alone.

Oxygen consumption, carbon dioxide production and metabolic rate

Table 1 shows that compared with saline-infused sheep, the addition of $\mathrm{NO}_{3}$ to sheep caused a decline $(P<0 \cdot 001)$ in $\mathrm{CO}_{2}$ production and a numerical decrease $(P>0.05)$ in $\mathrm{O}_{2}$ consumption and metabolic rate. When E. coli $\mathrm{W} 3110$ was inoculated to $\mathrm{NO}_{3^{-}}$ infused sheep, an increase $(P=0 \cdot 019)$ in $\mathrm{O}_{2}$ consumption and a numerical increase $(P>0.05)$ in $\mathrm{CO}_{2}$ production and metabolic rate were observed compared with sheep infused with $\mathrm{NO}_{3}$ alone.

\section{Ruminal fermentation characteristics}

Ruminal fermentation characteristics are shown in Table 2. Ruminal $\mathrm{pH}$ did not decrease in sheep given $\mathrm{NO}_{3}$ alone compared

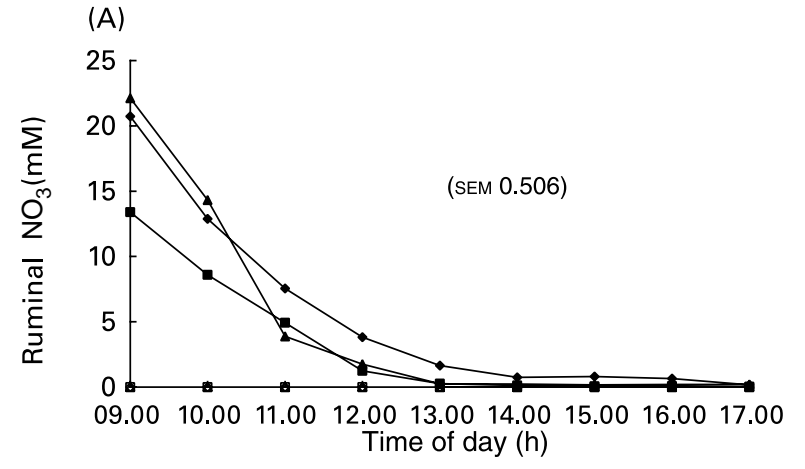

(B)

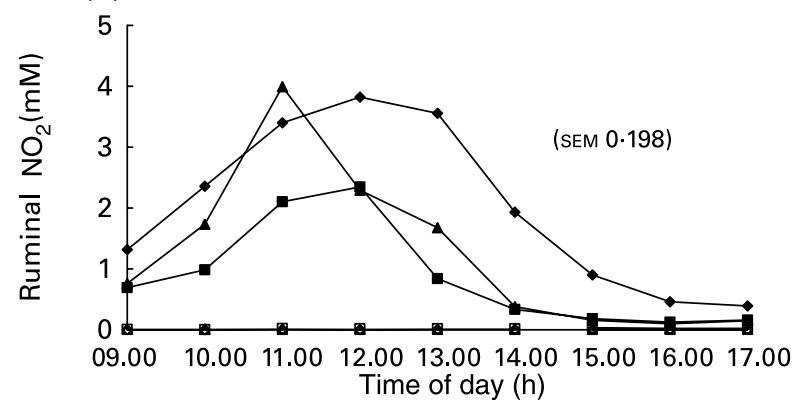

(C)
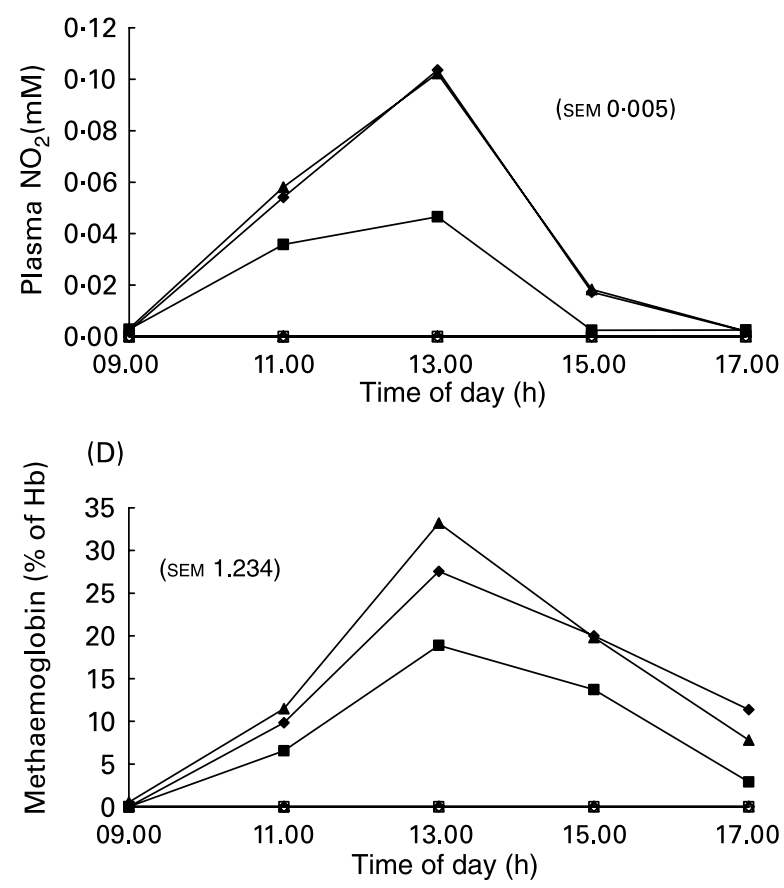

Fig. 2. Ruminal $\mathrm{NO}_{3}$ disappearance (A) and $\mathrm{NO}_{2}$ accumulation (B), plasma $\mathrm{NO}_{2}$ formation $(\mathrm{C})$, and formation of blood methaemoglobin (D) in sheep given $\mathrm{NO}_{3}(\bullet), \mathrm{NO}_{3}$ plus E. coli $\mathrm{W} 3110(\square)$ and $\mathrm{NO}_{3}$ plus E. coli nir-Ptac $(\mathbf{\Delta})$.

with saline-infused sheep. Compared with saline-infused sheep, ruminal $\mathrm{pH}$ decreased $(P=0 \cdot 044)$ in sheep inoculated with E. coli W3110 but increased $(P<0.001)$ in sheep inoculated with $E$. coli nir-Ptac. The ORP in sheep given $\mathrm{NO}_{3}$ increased $(P=0.0048)$ compared with saline-infused sheep. When $\mathrm{NO}_{3}$ was added to sheep, ruminal $\mathrm{NH}_{3}-\mathrm{N}$ concentration increased $(P<0 \cdot 001)$ compared with saline-infused sheep. Compared with 
sheep given $\mathrm{NO}_{3}$ alone, ruminal $\mathrm{NH}_{3}-\mathrm{N}$ concentration was unaffected by the inoculation of $E$. coli $\mathrm{W} 3110$ to $\mathrm{NO}_{3}$-infused sheep. Escherichia coli nir-Ptac caused an increase in $\mathrm{NH}_{3}-\mathrm{N}$ concentration in $\mathrm{NO}_{3}$-infused sheep. Compared with saline-infused sheep, an increase in total VFA concentration was observed in sheep given $\mathrm{NO}_{3}$ alone $(P=0 \cdot 016)$ and sheep inoculated with E. coli W3110 $(P=0.007)$ or E. coli nir-Ptac $(P=0.008)$. The administration of $\mathrm{NO}_{3}$ to sheep caused an increase $(P<0.001)$ in the molar proportion of acetate and a decrease $(P<0.001)$ in the molar proportions of propionate and butyrate. The inoculation of E. coli $\mathrm{W} 3110$ or E. coli nir-Ptac to $\mathrm{NO}_{3}$-infused sheep decreased $(P<0.001)$ the molar proportion of acetate and increased the molar proportions of propionate $(P<0.001)$ and butyrate $(P>0.05)$. Compared with saline-infused sheep, a numerical decrease $(P>0.05)$ in ciliate protozoa was observed in sheep given $\mathrm{NO}_{3}$ and in sheep inoculated with $E$. coli W3110 or E. coli nir-Ptac. Compared with sheep given $\mathrm{NO}_{3}$ alone, the inoculation of E. coli $\mathrm{W} 3110$ to sheep given $\mathrm{NO}_{3}$ numerically increased $(P>0.05)$ the ciliate protozoa.

\section{Discussion}

Several reports have shown that $\mathrm{CH}_{4}$ production in the rumen was efficiently reduced by the administration of $\mathrm{NO}_{3}$ (Jones, 1972; Takahashi \& Young, 1991; Anderson \& Rasmussen, 1998; Sar et al. 2004a). Our results showed that $\mathrm{CH}_{4}$ emission was remarkably inhibited when the sheep were administered with $\mathrm{NO}_{3}$, which is in agreement with these reports. This inhibition has been known to be due to $\mathrm{NO}_{3}$ reduction in the rumen effectively competing with ruminal $\mathrm{CH}_{4}$ production for electrons generated during fermentation (Allison \& Reddy, 1990). Additionally, Allison \& Reddy (1990) also reported that as the free-energy change ( $\Delta G$ ó) in the reactions concerned is as follows:

$$
\begin{gathered}
\mathrm{NO}_{3}^{-}+2 \mathrm{H}^{+}+4 \mathrm{H}_{2} \rightarrow \mathrm{NH}_{4}^{+}+3 \mathrm{H}_{2} \mathrm{O} ; \Delta G \text { ó }=-598 \mathrm{~kJ} / \text { reaction } \\
4 \mathrm{H}_{2}+\mathrm{CO}_{2} \rightarrow \mathrm{CH}_{4}+2 \mathrm{H}_{2} \mathrm{O} ; \Delta G \text { ó }=-131 \mathrm{~kJ} / \text { reaction }
\end{gathered}
$$

then $\mathrm{NO}_{3}$ reduction acts as a highly competitive $\mathrm{H}_{2}$ sink against ruminal methanogenesis. The ORP of microbial cultures is a measure of the degree of anaerobiosis in the growth environment
(Marais et al. 1988). For normal growth, the predominant ruminal micro-organisms require a low ORP value in the ambient medium, and ORP values of $-300 \mathrm{mV}$ or less have been reported for the ruminal contents of cattle (Smith \& Hungate, 1958) and for the growth of methanogens (Stewart \& Bryant, 1988). This study showed that when $\mathrm{NO}_{3}$ was administered to sheep, the value of ORP increased to $-290 \mathrm{mV}$ compared with salineinfused sheep. Another, albeit less likely, reason for the inhibition of $\mathrm{CH}_{4}$ emission from sheep by $\mathrm{NO}_{3}$ may be, therefore, that the very low ORP required for the metabolism of ruminal methanogens is not sustained.

When ruminants consume forage or water containing high levels of $\mathrm{NO}_{3} \mathrm{NO}_{3}$ intoxication was observed in the host because of the toxic accumulation of $\mathrm{NO}_{2}$ in the rumen and plasma, inducing the production of blood methaemoglobin (Takahashi \& Young, 1991, 1992; Sar et al. 2004a). This study showed that the toxic accumulation of $\mathrm{NO}_{2}$ in the rumen and plasma respectively was at its peak $4 \mathrm{~h}$ and $5 \mathrm{~h}$ after the sheep were given $\mathrm{NO}_{3}$ (Fig. 2 (B) and $(\mathrm{C})$ ), which is consistent with previous findings (Takahashi \& Young, 1991; Sar et al. 2004b). An increase in rate of ruminal $\mathrm{NO}_{3}$ disappearance, as well as a marked decrease in both peak and mean toxic $\mathrm{NO}_{2}$ accumulation in the rumen and plasma, were observed in sheep given $\mathrm{NO}_{3}$ plus $E$. coli $\mathrm{W} 3110$ compared with sheep given $\mathrm{NO}_{3}$ alone. This result is contrary to in vitro findings (Sar et al. 2005a) that E. coli W3110 did not decrease toxic $\mathrm{NO}_{2}$ accumulation in mixed ruminal cultures supplemented with $\mathrm{NO}_{3}$ using the basal diet of orchard grass hay (in $\mathrm{g} / \mathrm{kg}$; DM 873.3 OM $989.8 \%$, CP 14 hrs \%, ADF 388.4, NDF 732.6, ADL 41.0\%, GE: $4.45 \mathrm{Mcal}$, as DM basis), but supports our expectation that concentrate containing in diet supplies electrons for $E$. coli W3110 to accelerate $\mathrm{NO}_{3} / \mathrm{NO}_{2}$ reduction in the rumen.

However, the inoculation of E. coli W3110 to the $\mathrm{NO}_{3}$-infused sheep did not change the effect of $\mathrm{NO}_{3}$ on $\mathrm{CH}_{4}$ production. This may be due to $\mathrm{NO}_{3}$ having a more potent effect than E. coli W3110 on ruminal methanogenesis. When E. coli nir-Ptac was inoculated to $\mathrm{NO}_{3}$-infused sheep, $\mathrm{NO}_{2}$ accumulation seemed to be unaffected, although it was initially decreased and then rapidly declined after the peak values at $3 \mathrm{~h}$ obtained compared with sheep given $\mathrm{NO}_{3}$ alone and sheep given $\mathrm{NO}_{3}$ plus E. coli W3110. These results do not support the hypothesis that $E$. coli

\begin{tabular}{|c|c|c|c|c|c|c|c|c|}
\hline \multirow[b]{2}{*}{ Parameters } & \multicolumn{6}{|c|}{ Treatment } & \multirow[b]{2}{*}{ SEM } & \multirow{2}{*}{$\begin{array}{l}\text { Statistical } \\
\text { significance } \\
\text { of effect: } P\end{array}$} \\
\hline & Saline & E. coli W3110 & E. coli nir-Ptac & $\mathrm{NO}_{3}$ & $\begin{array}{c}\mathrm{NO}_{3} \text { plus } \\
\text { E. coli W3110 }\end{array}$ & $\begin{array}{c}\mathrm{NO}_{3} \text { plus } \\
\text { E. coli nir-Ptac }\end{array}$ & & \\
\hline Ruminal pH & $6 \cdot 47^{\mathrm{a}}$ & $6 \cdot 37^{\mathrm{b}}$ & $6 \cdot 63^{\mathrm{C}}$ & $6 \cdot 48^{\mathrm{a}}$ & $6 \cdot 43^{\mathrm{a}}$ & $6 \cdot 43^{\mathrm{a}}$ & 0.038 & 0.0001 \\
\hline Ruminal redox potential (mV) & $-319^{a}$ & $-316^{a}$ & $-319^{a}$ & $-294^{c}$ & $-308^{a, b}$ & $-290^{\mathrm{b}, \mathrm{c}}$ & 8.008 & 0.0004 \\
\hline Total VFA (mм) & $84 \cdot 64^{\mathrm{a}}$ & $95 \cdot 48^{\mathrm{b}}$ & $94 \cdot 76^{b}$ & $87 \cdot 81^{b}$ & $86 \cdot 81^{a, b}$ & $103 \cdot 89^{c}$ & 3.004 & 0.0001 \\
\hline \multicolumn{9}{|l|}{ Molar $\%$ of VFA } \\
\hline Acetate & $75 \cdot 72^{\mathrm{a}}$ & $76 \cdot 87^{\mathrm{a}}$ & $74 \cdot 81^{\mathrm{b}}$ & $79 \cdot 15^{\mathrm{c}}$ & $76 \cdot 56^{d}$ & $77 \cdot 14^{\mathrm{a}}$ & 0.343 & 0.0001 \\
\hline Propionate & $12 \cdot 42^{\mathrm{a}}$ & $12 \cdot 91^{\mathrm{c}}$ & $12 \cdot 76^{\mathrm{c}}$ & $11 \cdot 24^{\mathrm{b}}$ & $14 \cdot 16^{c}$ & $14.06^{\mathrm{a}, \mathrm{c}}$ & 0.258 & 0.0001 \\
\hline Butyrate & $10 \cdot 05^{\mathrm{a}}$ & $9 \cdot 05^{\mathrm{b}}$ & $10 \cdot 37^{a}$ & $6 \cdot 77^{\mathrm{c}}$ & $7 \cdot 45^{\mathrm{c}}$ & $7 \cdot 00^{c}$ & 0.188 & 0.0001 \\
\hline Other VFA† & $1 \cdot 81^{\mathrm{a}, \mathrm{e}}$ & $1 \cdot 16^{\mathrm{a}, \mathrm{d}}$ & $2 \cdot 07^{\mathrm{b}}$ & $1 \cdot 17^{\mathrm{c}, \mathrm{d}}$ & $1 \cdot 83^{\mathrm{a}, \mathrm{e}}$ & $1.79^{\mathrm{e}}$ & 0.157 & 0.0001 \\
\hline Acetate:propionate ratio & $6 \cdot 29^{a}$ & $6 \cdot 23^{\mathrm{b}}$ & $6 \cdot 03^{a, b}$ & $8.09^{c}$ & $5 \cdot 50^{a, b}$ & $5 \cdot 57^{a, b}$ & 0.243 & 0.0001 \\
\hline $\mathrm{NH}_{3}-\mathrm{N}(\mathrm{mg} / \mathrm{l})$ & $181^{\mathrm{a}}$ & $179^{a}$ & $190^{\mathrm{a}}$ & $289^{b}$ & $287^{\mathrm{b}}$ & $316^{\mathrm{c}}$ & $7 \cdot 817$ & 0.0001 \\
\hline Ciliate protozoa $\left(\times 10^{5} / \mathrm{ml}\right) \ddagger$ & $12 \cdot 80$ & 9.95 & 9.50 & $5 \cdot 44$ & $9 \cdot 81$ & 8.33 & $2 \cdot 278$ & 0.2334 \\
\hline
\end{tabular}

Table 2. Ruminal fermentation characteristics in sheep given $\mathrm{NO}_{3}$ and/or Escherichia coli W3110 or E. coli nir-Ptac*

VFA, volatile fatty acids.

${ }^{*}$ All values are mean of nine sampling times unless otherwise indicated.

abcde Mean values within a row with unlike superscript letters were significantly, different $(P<0.05)$. Each value indicates means of four animals

$\dagger$ Including valeric, isovaleric and isobutyric fatty acids.

$\ddagger$ Value indicates the mean of sampling times at $5 \mathrm{~h}$. 
nir-Ptac, via a potential of tac promoter, has a greater ability than wild-type E. coli W3110 to inhibit toxic $\mathrm{NO}_{2}$ accumulation. This may be due to E. coli nir-Ptac not accelerating the activity of $\mathrm{NO}_{3}$ reductase compared with $E$. coli $\mathrm{W} 3110$. Another reason is that as $\mathrm{NO}_{3}$ reduction was accelerated by the inoculation of $E$. coli nirPtac (Fig. 2 (A)), $\mathrm{NO}_{2}$ reduction in E. coli nir-Ptac may be limited by an insufficient electron supply in the present experiment. It has been reported that $\mathrm{NO}_{2}$ reduction in $E$. coli strains was promoted by electron donors such as formate (Abou-Jaoudé et al. 1977) and especially pyruvate when strains of $E$. coli were deficient in NADH- $\mathrm{NO}_{2}$ reductase activity and unable to produce formate from pyruvate owing to a lack of pyruvate formate-lyase activity (acetyl-CoA: formate $C$-acetyltransferase; EC 2.3.1.54; Pascal et al. 1981).

The administration of $\mathrm{NO}_{3}$ to sheep in the present study produced a methaemoglobin level of $27.5 \%$ of total $\mathrm{Hb}$, which is comparable with the previous finding (Bodansky, 1951) reporting that an $\mathrm{NO}_{3}$-induced methaemoglobin content of about $20 \%$ of total $\mathrm{Hb}$ is considered subclinically toxic to ruminants. $\mathrm{O}_{2}$ consumption, $\mathrm{CO}_{2}$ production and metabolic rate in sheep given $\mathrm{NO}_{3}$ alone were numerically decreased compared with salineinfused sheep, which is consistent with the findings of others (Takahashi \& Young, 1991, 1992). These may result from the progressive production of $\mathrm{NO}_{3}$-induced blood methaemoglobin. It has been reported that every $10 \%$ replacement of oxyhaemoglobin with methaemoglobin reduced $\mathrm{O}_{2}$ consumption by $10 \cdot 3 \%$ in sheep (Takahashi et al. 1998). The inoculation of E. coli $\mathrm{W} 3110$ into $\mathrm{NO}_{3}$-infused sheep decreased both peak and mean blood methaemoglobin production, which may be explained by the fact that $E$. coli $\mathrm{W} 3110$ accelerated $\mathrm{NO}_{3} / \mathrm{NO}_{2}$ reduction in the rumen; consequently, toxic $\mathrm{NO}_{2}$ accumulation in the rumen as well as in the plasma was decreased, as described earlier. Numerical increases in $\mathrm{O}_{2}$ consumption, $\mathrm{CO}_{2}$ production and metabolic rate in sheep given $\mathrm{NO}_{3}$ plus E. coli W3110 compared with sheep given $\mathrm{NO}_{3}$ alone were due to the decrease in blood methaemoglobin production resulting from the ability of E. coli W3110 to reduce $\mathrm{NO}_{2}$ to $\mathrm{NH}_{3}$. When E. coli nir-Ptac was inoculated into $\mathrm{NO}_{3}$-infused sheep, blood methaemoglobin production was unaffected compared with sheep given $\mathrm{NO}_{3}$ alone; this explains the lack of decline in ruminal and plasma $\mathrm{NO}_{2}$ accumulation observed in sheep given $\mathrm{NO}_{3}$ plus E. coli nir-Ptac.

An increased ruminal $\mathrm{NH}_{3}-\mathrm{N}$ concentration associated with $\mathrm{NO}_{3}$ supplementation has previously been reported (Lewis, 1951), confirmed by the result in the present study. This is the result of $\mathrm{NO}_{3}$ reduction to $\mathrm{NH}_{3}$. The inoculation of $E$. coli $\mathrm{W} 3110$ to $\mathrm{NO}_{3}$-infused sheep did not affect ruminal $\mathrm{NH}_{3}-\mathrm{N}$ concentration compared with sheep given $\mathrm{NO}_{3}$ alone, and this does not support the hypothesis that when E. coli $\mathrm{W} 3110$ was inoculated to $\mathrm{NO}_{3}$-infused sheep, it accelerated ruminal $\mathrm{NO}_{3}$ and $\mathrm{NO}_{2}$ reduction, causing the fall in ruminal toxic $\mathrm{NO}_{2}$ accumulation; consequently, ruminal $\mathrm{NH}_{3}-\mathrm{N}$ concentration should be high.

It was reported that the reduction in the number of protozoa could explain the higher total VFA concentration (Nollet et al. 1998) although a considerable number of reports showing the negative effects of defaunation on VFA production have been published (Williams \& Coleman, 1995). The stimulation of total VFA concentration by E. coli $\mathrm{W} 3110$ or E. coli nir-Ptac in this study may account for the decrease in the number of ciliate protozoa. The inoculation of E. coli $\mathrm{W} 3110$ or E. coli nir-Ptac decreased $\mathrm{CH}_{4}$ emission from sheep by $6 \%$ and $12 \%$, respectively (Table 1 ), which is consistent with our in vitro results
(Sar et al. 2005b). This decrease may account for a decrease in number and/or activity of ciliate protozoa by the inoculation of E. coli $\mathrm{W} 3110$ or E. coli nir-Ptac. It has been reported that ruminal methanogens are known to be associated with ciliate protozoa (Stumm et al. 1982; Finlay et al. 1994), and a disruption of this cohabitation may decrease $\mathrm{CH}_{4}$ production (Nollet et al. 1998).

The increase in the molar proportion of acetate, and the decrease caused by $\mathrm{NO}_{3}$ supplementation in the molar proportions of propionate and butyrate, in the present study confirmed previous reports (Farra \& Satter, 1971; Nakamura et al. 1981; Takahashi et al. 1989; Sar et al. 2004b), and these could reflect the electron sink of $\mathrm{NO}_{3}$ in rumen fermentation (Farra \& Satter, 1971). Although the addition of E. coli W3110 did not change the effect of $\mathrm{NO}_{3}$ on ruminal $\mathrm{CH}_{4}$ production in sheep, a decrease in acetate:propionate ratio was observed. Moss and Givens (2002) reported that rumen stoichiometry could not explain the change in $\mathrm{CH}_{4}$ production.

\section{Conclusion}

The present study has shown that $\mathrm{NO}_{3}$ inhibited $\mathrm{CH}_{4}$ emission from sheep via its reduction directing reductant away from $\mathrm{CH}_{4} \cdot \mathrm{CH}_{4}$ emission from sheep was abated by the inoculation of wild-type E. coli $\mathrm{W} 3110$ or E. coli nir-Ptac, although the underlying mechanism has not been elucidated. Compared with sheep given $\mathrm{NO}_{3}$ alone, the inoculation of E. coli $\mathrm{W} 3110$ to $\mathrm{NO}_{3}$-infused sheep abated ruminal and plasma toxic $\mathrm{NO}_{2}$ accumulation and blood methaemoglobin production, while keeping methanogenesis low. Ruminal and plasma toxic $\mathrm{NO}_{2}$ accumulation and blood methaemoglobin production were unaffected by the inoculation of E. coli nir-Ptac. It is suggested that $\mathrm{CH}_{4}$ emission from sheep may be reduced by the inoculation of wild-type E. coli $\mathrm{W} 3110$ or E. coli nir-Ptac. The inoculation of wild-type E. coli $\mathrm{W} 3110$ may abate $\mathrm{NO}_{3} / \mathrm{NO}_{2}$ toxicity when $\mathrm{NO}_{3}$ is potentially applied to inhibit $\mathrm{CH}_{4}$ mission from ruminants. Further research is required, however, to verify the long-term efficacy of wild-type E. coli $\mathrm{W} 3110$ as well as E. coli nir-Ptac on $\mathrm{NO}_{3} / \mathrm{NO}_{2}$ reduction in vitro and in vivo.

\section{Acknowledgements}

The authors thank Professor Dr Satoshi Hidaka (Obihiro University of Agriculture and Veterinary Medicine, Obihiro, Hokkaido, Japan) for his skilled technical assistance in enumerating ruminal ciliate protozoa and in analysing ruminal $\mathrm{NO}_{3}$ and $\mathrm{NO}_{2}$ concentration in the rumen and plasma.

\section{References}

Abou-Jaoudé A, Chippaux M, Pascal MC \& Casse F (1977) Formate: a new electron donor for nitrite reduction in Escherichia coli K12. Biochem Biophys Res Commun 78, 579-583.

Allison MJ \& Reddy CA (1990) Adaptations of gastrointestinal bacteria in response to changes in dietary oxalate and nitrate. Vet Hum Toxicol 32, 248-256.

Anderson RC \& Rasmussen MA (1998) Use of a novel nitrotoxin-metabolizing bacterium to reduce ruminal methane production. Bioresour Technol 64, 89-95.

Bodansky O (1951) Methaemoglobinemia and methaemoglobin-producing compounds. Pharmacol Rev 3, 144-196.

Brouwer E (1960) On simple formulae for calculating the heat expenditure and quantities of carbohydrate and fat metabolized in ruminants from data on gaseous exchange and urine-N. In Energy Metabolism, 
pp. 182-192 [G Thorbek and H Aerøe, editors]. EAAP Publication no. 8. Copenhagen: EAAP.

Evelyn KA \& Malloy HT (1938) Microdetermination of oxyhaemoglobin, methaemoglobin, and sulfhaemoglobin in single sample of blood. J Biol Chem 126, 655-662.

Farra PA \& Satter LD (1971) Manipulation of the ruminal fermentation. III. Effects of nitrate on ruminal volatile fatty acid production and milk composition. J Dairy Sci 54, 1018-1024.

Finlay BJ, Esteban G, Clarke KJ, Williams AG, Embley TM \& Hirt RP (1994) Some ciliates have endosymbiotic methanogens. FEMS Microbiol Lett 117, 157-162.

Gennis RB \& Stewart V (1996) Respiration. In Escherichia coli and Salmonella: Typhimurium Cellular and Molecular Biology, 2nd ed. vol. 1, pp. 217-261 [FC Neidhardt, R Curtiss, JL Ingramham, et al. editors]. Washington, DC: ASM Press.

Hungate RE (1966) The Rumen and its Microbes. New York: Academic Press.

Johnson KA \& Johnson DE (1995) Methane emissions from cattle. J Anim Sci 73, 2483-2492.

Jones GA (1972) Dissimilatory metabolism of nitrate by the rumen microbiota. Can J Microbiol 18, 1783-1789.

Lewis D (1951) The metabolism of nitrate and nitrite in the sheep. I. The reduction of nitrate in the rumen of the sheep. Biochem J 48, 175-180.

Littell RC, Henry PR \& Ammerman CB (1998) Statistical analysis of repeated measures data using SAS procedures. J Anim Sci 76, $1216-1231$.

López S, Valdés C, Newbold CJ \& Wallace RJ (1999) Influence of sodium fumarate addition on rumen fermentation in vitro. Br J Nutr 81, 59-64.

McDougall EI (1948) Studies on ruminant saliva. I. The composition and output of sheep's saliva. Biochem J 43, 99-109.

Marais JP, Therion JJ, Mackie RI, Kistner A \& Dennison C (1988) Effect of nitrate and its reduction products on the growth and activity of the rumen microbial population. Br J Nutr 59, 301-313.

Matsuyama S \& Mizushima S (1985) Construction and characterization of a deletion mutant lacking $m i c F$, a proposed regulatory gene for $\mathrm{ompF}$ synthesis in Escherichia coli. J Bacteriol 162, 1196-1202.

Moss AR (1993) Methane: Global Warming and Production by Animals. Canterbury: Chalcombe Publications.

Moss AR \& Givens DI (2002) The effect of supplementing grass silage with soya bean meal on digestibility, in sacco degradability, rumen fermentation and methane production in sheep. Anim Feed Sci Technol 97, 127-143.

Nakamura Y, Tada Y, Saito T, Yoshida J \& Nakamura R (1981) Nitrate metabolism of microorganisms in the rumen of sheep fed high nitrate Italian ryegrass silage. Jpn J Zootech Sci 52, 512-518.

Nollet L, Mbanzamihigo L, Demeyer D \& Verstraete W (1998) Effect of the addition of Peptostreptococcus productus ATCC 35244 on reductive acetogenesis in the ruminal ecosystem after inhibition of methanogenesis by cell-free supernatant of Lactobacillus plantarum 80. Anim Feed Sci Technol 71, 49-66.
Ogimoto KJ \& Imai S (1981) Atlas of Rumen Microbiology, pp. 71-125. Japan: Scientific Societies Press.

Pascal MC, Chippaux M, Abou-Jaoudé A, Blaschkowski HP \& Knappe J (1981) Mutants of Escherichia coli K12 with defects in anaerobic pyruvate metabolism. J Gen Microbiol 124, 35-42.

Sar C, Mwenya B, Santoso B, Morikawa R, Isogai N, Asakura Y, Toride Y \& Takahashi J (2005a) Effects of Escherichia coli W3110 on ruminal methanogenesis and nitrate/nitrite reduction in vitro. Anim Feed Sci Technol 118, 295-306.

Sar C, Mwenya B, Santoso B, Takaura K, Morikawa R, Isogai N, Asakura Y, Toride Y \& Takahashi J (2005b) Effect of Escherichia coli wild type or its derivative with high nitrite reductase activity on in vitro ruminal methanogenesis and nitrate/nitrite reduction. $J$ Anim Sci 83, 552-644.

Sar C, Santoso B, Gamo Y, Kobayashi T, Shiozaki S, Kimura K, Mizukoshi $\mathrm{H}$, Arai I \& Takahashi J (2004a) Effects of combination of nitrate with $\beta$ 1-4 galacto-oligosaccharides and yeast (Candida kefyr) on methane emission from sheep. Asian-Aust J Anim Sci 17, 73-79.

Sar C, Santoso B, Mwenya B, Gamo Y, Kobayashi T, Morikawa R, Kimura K, Mizukoshi H \& Takahashi J (2004b) Manipulation of rumen methanogenesis by the combination of nitrate with $\beta$ 1-4 galacto-oligosaccharides or nisin in sheep. Anim Feed Sci Technol 115, 129-142.

Smith PH \& Hungate RE (1958) Isolation and characterization of Methanobacterium ruminantium $\mathrm{n}$. Sp. J Bacteriol 75, 713-718.

Stewart CS \& Bryant MP (1988) The rumen bacteria. In The Rumen Microbial Ecosystem, pp. 21-75 [PN Hobson, editor]. London and New York: Elsevier Applied Science.

Stumm CK, Gijzen HJ \& Vogels GD (1982) Association of methanogenic bacteria with ovine rumen ciliates. Br J Nutr 47, 95-99.

Takahashi J, Ikeda M, Matsuoka S \& Fujita H (1998) Prophylactic effect of L-cysteine to acute and subclinical nitrate toxicity in sheep. Anim Feed Sci Technol 74, 273-280.

Takahashi J, Johchi N \& Fujita H (1989) Inhibitory effects of sulphur compounds, copper and tungsten on nitrate reduction by mixed rumen micro-organisms. Br J Nutr 61, 741-748.

Takahashi J \& Young BA (1991) Prophylactic effect of L-cysteine on nitrate-induced alteration in respiratory exchange and metabolic rate in sheep. Anim Feed Sci Technol 35, 105-113.

Takahashi J \& Young BA (1992) The modulation of nitrate-enhanced hypothermia by sulphur compounds in cold-exposed sheep. Anim Feed Sci Technol 39, 347-355.

Van Kessel JAS \& Rusell JB (1996) The effect of pH on ruminal methanogenesis. FEMS Microbiol Ecol 20, 205-210.

Van Nevel CJ \& Demeyer DI (1996) Control of rumen methanogenesis. Environ Monit Assess 42, 73-97.

Williams AG \& Coleman GS (1995) The rumen protozoa. In The Rumen Microbial Ecosystem, pp. 77-127 [PN Hobson, editor]. London: Elsevier. 